\title{
Modernizacja systemów ESD na toczniach gazu
}

\begin{abstract}
Celem artykułu jest pokazanie nowoczesnego podejścia do realizacji projektów modernizacji istniejących systemów bezpieczeństwa i sterowania obiektami technologicznymi na przykładzie tłoczni gazu. Podejmowane działania mają za zadanie utrzymanie infrastruktury na odpowiednim poziomie funkcjonalności i bezpieczeństwa, ale nie ograniczają się tylko do tego. Publikacja przedstawia podejście EuRoPol GAZ S.A. do systemowego postępowania przy wyborze systemów podlegających modernizacji lub rozbudowie z uwzględnieniem zmieniającego się otoczenia i technologii.
\end{abstract}

Słowa kluczowe: systemy ESD, modernizacja, tłocznia gazu, gaz ziemny.

\section{Modernisation of ESD systems for gas compressor stations}

The aim of the paper is to present a modern approach to the realization of upgrading projects for existing security systems and control of technological objects on the example of gas compressor stations. The actions undertaken are designed to maintain the infrastructure not only at the appropriate level of functionality and safety. The publication presents the EuRoPol GAZ S.A. approach to systemic procedure for the selection of systems subject to modernization or expansion, taking into account the changing environment and technology.

Key words: ESD systems, modernisation, gas compressor station, natural gas.

\section{Wstęp}

System gazociągów tranzytowych Jamał-Europa (SGT) na terytorium Rzeczypospolitej Polskiej jest częścią gazociągu biegnącego z Rosji, z półwyspu Jamał, poprzez Białoruś i Polskę do Europy Zachodniej. Projekt SGT zakładał budowę dwóch nitek gazociągu DN 1400 o długości około 684,7 km każda. Obecnie przekazana jest do eksploatacji północna nitka gazociągu wraz z pięcioma tłoczniami gazu i stacjami pomiarowymi o zainstalowanej łącznej mocy agregatów sprężających wynoszącej $400 \mathrm{MW}$.

Wymagania odnośnie do systemów automatyki i sterowania w EuRoPol GAZ wiążą się z potrzebą zapewnienia: wysokiego stopnia niezawodności i bezpieczeństwa pracy gazociągu, ekonomiki transportu gazu, precyzji sterowania (wykonanie zadania transportowego w zakresie ilości gazu i ciśnienia dostawy), dokładności rozliczeń, a także pracy systemów łączności technologicznej i SCADA.

Właścicielem polskiego odcinka SGT jest firma System Gazociągów Tranzytowych EuRoPol GAZ S.A. w Warszawie. Funkcję operatora SGT EuRoPol GAZ pełni firma GAZ-SYSTEM S.A. Od początku działalności EuRoPol GAZ do końca 2015 roku przetransportowano 430 miliardów metrów sześciennych gazu (według GOST). Ze względu na wysokie zdolności przesyłowe, jak również brak alternatywnego sposobu transportu gazu zapewnienie bezpieczeństwa i niezawodności pracy stanowi dla EuRoPol GAZ kluczowe zagadnienie.

Początek budowy SGT EuRoPol GAZ nastąpił w 1996 roku. W 2005 roku, po uruchomieniu ostatniej budowanej tłoczni - Zambrów, osiągnięta została projektowa moc przesyłowa gazociągu. W 2008 roku podjęto prace mające na celu analizę bezpieczeństwa i niezawodności SGT. Od początku tych prac EuRoPol GAZ zależało na systemowym działaniu zmierzającym do zwiększenia bezpieczeństwa ludzi i środowiska oraz na wysokiej niezawodności świadczonych usług transportu gazu, w zgodzie z obowiązującymi przepisami.

W niniejszym artykule skoncentrowano się na systemach bezpieczeństwa i sterowania tłoczni, których praca gwarantuje możliwość realizowania zadań SGT. Systemy bezpieczeństwa i sterowania tłocznią są w swojej funkcjonalności połączone i należy je rozpatrywać łącznie. 


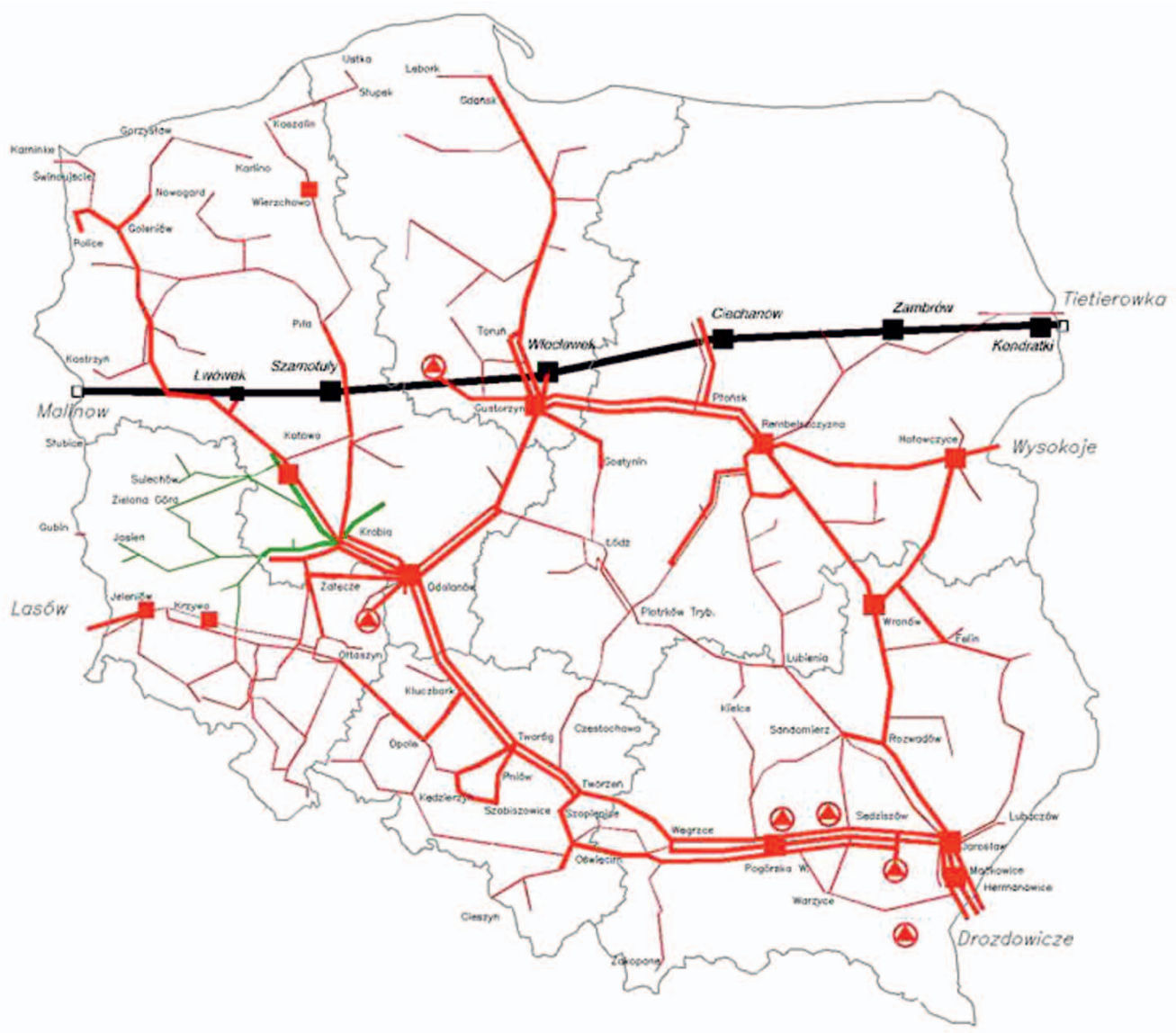

Rys. 1. Przebieg gazociągu i położenie tłoczni SGT EuRoPol GAZ na tle krajowego systemu przesyłowego

\section{Analizy systemów bezpieczeństwa}

Podstawą do podjęcia działań inwestycyjnych przez EuRoPol GAZ S.A. było przeprowadzenie wstępnych analiz pracy systemów pod kątem zgodności z obowiązującymi przepisami oraz dokonanie oceny eksploatacyjnej systemów sterowania i zabezpieczeń z analizą ich wpływu na koszty eksploatacji. W ramach prac istotne było porównanie wartości sygnałów mierzonych na obiekcie z wynikami otrzymanymi za pomocą aparatury kontrolnej.

W pierwszej kolejności oceniono koszty eksploatacji (wraz kosztami napraw serwisowych). Następnym krokiem było przeprowadzenie kompleksowych analiz: HAZOP ( $h a-$ zard and operability study - analiza zagrożeń i zdolności operacyjnych) układów technologicznych, C-HAZOP (analiza zagrożeń i zdolności operacyjnych automatyki) systemów automatyki, LOPA (layer of protection

URZĄDZENIA AUTOMATYKI

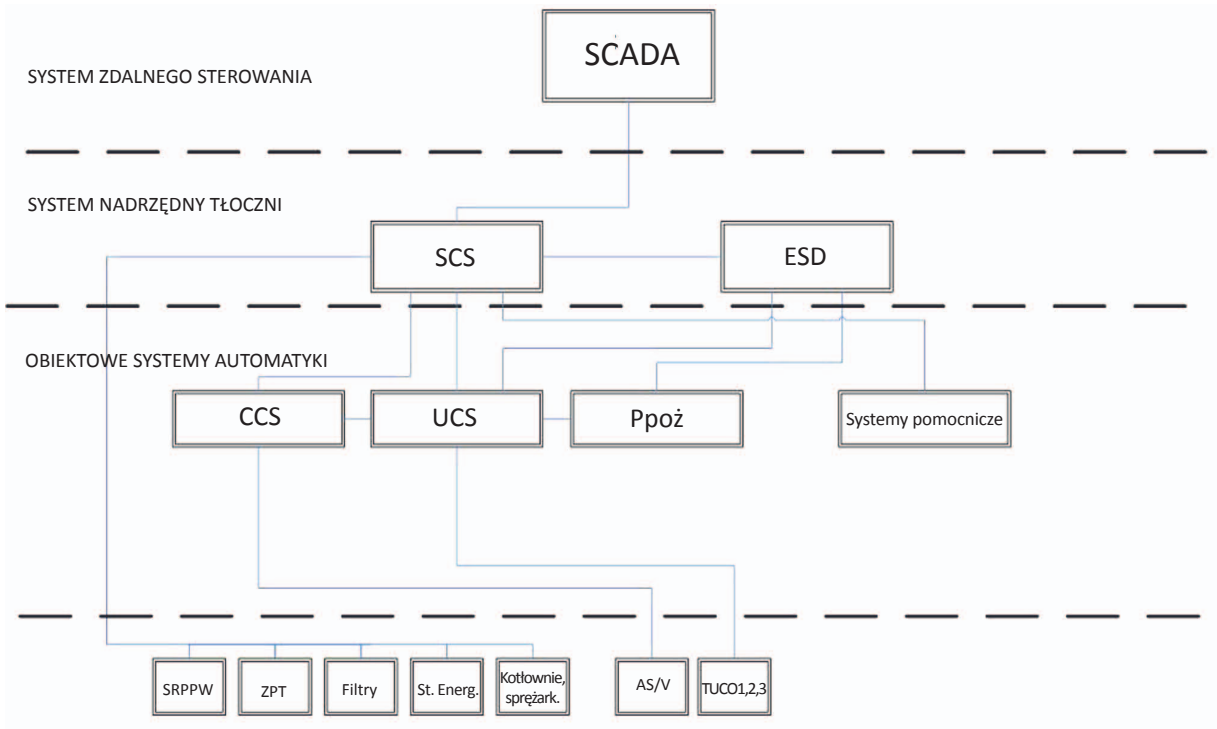

Rys. 2. Architektura systemów automatyki tłoczni gazu analysis - analiza warstw ochrony) i SIL (safety integrity level - poziom nienaruszalności bezpieczeństwa) systemów zabezpieczeń. 
Wnioski z analiz posłużyły do przygotowania wytycznych przy tworzeniu specyfikacji istotnych warunków zamówienia (SIWZ) na wykonanie modernizacji systemów bezpieczeństwa i sterowania. Celem modernizacji systemów była poprawa funkcjonalności i znaczne podniesienie bezpieczeństwa personelu, urządzeń i pewności wypełnienia zawartych umów na tranzyt gazu.

Głównym systemem automatyki na tłoczni jest Nadrzędny System Sterowania Tłocznią, w którego skład wchodzą: system SCS (Station Control Solution) - system sterowania tłocznią, system ESD (Emergency Shutdown System) - system awaryjnego odstawienia oraz system antypompażu (Continuous Control System firmy CCS). Nadrzędny System Sterowania Tłocznią jest odpowiedzialny za sterowanie tłocznią, za komunikację z systemem SCADA oraz wszystkimi pozostałymi systemami automatyki na tłoczni gazu oraz za wizualizację stanów obiektu i wykonywanie komend dyspozytora tłoczni. Architekturę systemów automatyki tłoczni gazu przedstawiono na rysunku 2.

W 2010 roku UDT-CERT ${ }^{1}$ wykonał analizy zagrożeń i ryzyka dla tłoczni Kondratki (HAZOP, C-HAZOP). Celem analizy HAZOP było zidentyfikowanie zagrożeń i problemów operacyjnych instalacji oraz zbadanie możliwych ich przyczyn i ocena skutków. W ramach analizy C-HAZOP rozpoznano zagrożenia i problemy operacyjne instalacji pochodzące od układów sterowania i regulacji. Przeprowadzenie analiz wymagało zebrania danych o procesie $\mathrm{i}$ instalacji, dokonania podziału systemu na podsystemy i dokładnego opisu ich funkcjonowania, a także określenia istotnych parametrów wpływających na przebieg procesu. Dla celów analizy HAZOP podzielono instalację na 9, a dla celów C-HAZOP na 5 sekcji.

Bardzo istotną częścią pracy było wyznaczenie poziomu nienaruszalności SIL. Wykonana analiza warstw ochrony (LOPA) składała się z analizy przyczyn $\mathrm{i}$ analizy konsekwencji zdarzeń oraz ich kategorii. W wyniku tych prac zostały sformułowane zalecenia odnośnie do zabezpieczeń lub uzyskano potwierdzenie odpowiedniego poziomu zabezpieczeń. Zalecenia wykorzystano w kolejnych latach w stosunku do prac mających na celu zwiększenie bezpieczeństwa ludzi, instalacji i procesu.

Bardzo ważne dla zarządzania bezpieczeństwem i procesem modernizacji były:

- ocena zagrożenia wybuchem,

- ocena rozwiązań w zakresie projektu i eksploatacji systemu detekcji gazów wybuchowych,

- ocena rozwiązań w zakresie projektu i eksploatacji systemu sygnalizacji pożaru.

\section{Wdrożenie nowych rozwiązań}

Opisane wyżej wyniki analiz stały się w latach 2013-2015 podstawą do modernizacji systemów ESD na tłoczniach Kondratki i Włocławek, które otrzymały nową funkcjonalność oraz certyfikację SIL.

Plany na najbliższe lata obejmują między innymi: modernizację algorytmów sterowania turbokompresorów (TUCO)
1, 2, 3, 4 tłoczni Kondratki (rozdzielenie funkcji systemu sterowania i funkcji ESD dla automatycznego odstawienia z wydmuchem i bez wydmuchu gazu oraz ograniczenie ruchów automatycznych zaworów na wlocie i wylocie kompresora) oraz wymianę sterowników regulatorów turbin na tłoczniach Włocławek i Kondratki.

\section{System ESD - awaryjnego odstawienia tłoczni}

\section{Ogólny opis systemu}

Zabezpieczenia mają na celu sprowadzenie urządzeń lub ciągów technologicznych do stanu bezpiecznego, niepowodującego pojawienia się lub pogłębienia uszkodzeń, lub/i uniemożliwienie rozprzestrzeniania się skutków awarii na inne urządzenia, lub powstrzymanie skutków zagazowania, pożaru, braku energii elektrycznej itd.

Akcje podejmowane przez system ESD odbywają się bez udziału obsługi i obejmują zbiór czynności mający doprowadzić urządzenia do bezpiecznego stanu w jak naj-

\footnotetext{
${ }^{1}$ UDT CERT - jednostka certyfikująca działająca według norm europejskich, posiadająca akredytację PCA w zakresie certyfikacji systemów zarządzania, wyrobów i osób.
}

krótszym czasie przy zachowaniu wymagań technologicznych. Występują one tylko w przypadku aktywacji systemu zabezpieczeń.

Zabezpieczenia stanowią układ sterowania oddziałujący na układy automatyki (SCS) poprzez zezwolenie na wyjście danego urządzenia lub grupy ze stanu bezpiecznego i na jego normalne funkcjonowanie zgodnie z sygnałami z układu sterowania tłocznią SCS.

System sterowania tłocznią (SCS) w trakcie normalnej pracy również może realizować sekwencje odstawień urządzeń i ciągów, ale odbywa się to zgodnie z normalnymi potrzebami ruchowymi tłoczni i z zachowaniem wszelkich wymogów technologicznych. 


\section{Zadania systemu ESD}

Rolą systemu ESD jest bezpieczne wyłączenie całej tłoczni w sytuacji awaryjnej, gdy system centralny odmówiłby współpracy lub pojawiłyby się sygnały świadczące o uszkodzeniu lub nienormalnej pracy instalacji. System zabezpieczeń obejmuje system ESD (awaryjnego wyłączenia) dla turbosprężarek i całej tłoczni. ESD otrzymuje informacje z systemów detekcji pożaru i układów zabezpieczeń, dane procesowe oraz informacje z przycisków sprzętowych i przesyła te dane do zaworów, systemów sterowania agregatami turbosprężarek oraz innych układów wyłączających w celu bezpiecznego wyłączenia tłoczni w razie awarii.

Okablowanie do sterowania urządzeń wykonawczych objętych systemem ESD jest prowadzone odrębnymi trasami. ESD pracuje jako układ nadrzędny w stosunku do systemu sterowania tłocznią i systemów sterowania turbosprężarką tylko w zakresie realizacji funkcji zabezpieczeń na poziomie tłoczni oraz jako układ inicjujący odstawienie turbosprężarki w sytuacjach awaryjnych. W pozostałym zakresie funkcjo- nalności układ ESD jest kompletnie niezależny od systemu sterowania tłocznią. System ESD wykorzystuje technologię mikroprocesorową, co daje następujące korzyści:

- ciągły automatyczny test układu i sygnalizację nieprawidłowości w pracy,

- dużą pojemność pamięci sterownika - pozwalającą na implementację znacznej liczby algorytmów logiki zabezpieczeń,

- możliwość wymiany informacji, przyjmowania i transmitowania danych do systemu nadrzędnego, przechowywania danych i zarządzania nimi,

- wysoką niezawodność systemu,

- łatwość konfiguracji i serwisowania (możliwość wymiany modułów przy pracującym układzie),

- przechowywanie zawsze aktualnej dokumentacji w wersji elektronicznej i możliwość dostępu do niej w każdej chwili,

- łatwość sprawdzania i uruchomienia układu,

- monitorowanie przerw i zwarć linii.

\section{Modernizacja}

Modernizacja polegała na wymianie i uruchomieniu części systemu sterowania, w tym sterowników systemu ESD, na rozdzieleniu systemu sterowania tłocznią i ESD, oraz na funkcjonalnej separacji od istniejącego systemu sterowania tłocznią systemu zabezpieczeń przed pompażem kompresorów i rozdziału obciążeń pomiędzy poszczególnymi pracującymi kompresorami, sterownikami turbokompresorów i SCADA.

1. Zmodernizowany system bezpieczeństwa i sterowania posiada następującą funkcjonalność:

- podgląd i sterowanie procesem technologicznym w trybie ręcznym i automatycznym poprzez wykorzystanie obrazów (ekranów) procesowych i elementów interaktywnych (stacyjki);

- funkcjonalność stacyjek dopasowana do sygnałów analogowych/binarnych, napędów, grup funkcyjnych oraz sekwencji, obejmująca w swoim zakresie wprowadzanie komend oraz podgląd dynamicznych informacji dotyczących danego obiektu w czasie rzeczywistym;

- wizualizacja bieżących i archiwalnych danych pomiarowych (pomiary ESD);

- możliwość integracji i wyświetlania w oknie stacji operatorskiej powiązanych z danym obiektem informacji w postaci plików Windows, graficznych;

- wyświetlanie list alarmowych dla alarmów procesowych i systemowych z możliwością filtrowania i potwierdzania, konfiguracja alarmów dźwiękowych, zarządzanie alarmami;
- wyświetlanie list zdarzeń obejmujących alarmy i zdarzenia procesowe i systemowe z możliwością filtrowania;

- dostęp do okien wizualizacji statusu systemu w zakresie części programowej i sprzętowej;

- wyświetlanie danych bieżących i archiwalnych w postaci trendów prekonfigurowanych, jak również możliwość tworzenia trendów operatorskich z funkcją zrzucania danych do aplikacji zewnętrznych (Excel). Każdy wykres ma możliwość wyświetlania do ośmiu krzywych identyfikowanych poprzez zróżnicowaną kolorystykę, rodzaj linii lub oznaczenie numeryczne. Oś pozioma, będąca osią czasu, umożliwia operatorowi jej swobodne skalowanie i przewijanie w przód i wstecz;

- tworzenie raportów planowych oraz na żądanie;

- kompatybilność ESD z istniejącym systemem sterowania, łączność poprzez magistralę komunikacyjną;

- ciągła samodiagnostyka systemu z automatycznym lokalizowaniem i prezentacją miejsca awarii;

- oprogramowanie udostępnia wszystkie standardowe funkcje (narzędzia) programistyczne;

- oprogramowanie zabezpiecza przed błędami wynikającymi z przypadkowego wielokrotnego naciśnięcia klawisza powodującymi nieodwracalne zmiany danych lub realizację przypadkowego działania poprzez funkcję potwierdzenia wydawanego rozkazu;

- współpraca $\mathrm{z}$ istniejącymi redundantnymi magistralami systemowymi. 
2. Bezpieczeństwo zmodernizowanego systemu wykorzystuje:

- model bezpieczeństwa systemu Windows,

- konfigurowanie restrykcji dla użytkowników,

- monitorowanie,

- uwierzytelnianie i podpis cyfrowy,

- funkcje ochrony aplikacji SIL w sterownikach,

- kontrolę dostępu i uwierzytelnienie,

- zarządzanie symulacjami,

- potwierdzenie zapisu/potwierdzenie operacji,

- wbudowane zapory i procedury potwierdzania zabezpieczające aplikacje SIL przed nieumyślnymi/przypadkowymi działaniami.

3. Zgodność z normami bezpieczeństwa funkcjonalnego

Projekt modernizacji systemu ESD dla tłoczni gazu Kondratki i Włocławek jest zgodny z wymaganiami przedstawionymi w następujących normach:

- IEC 61508 - Bezpieczeństwo funkcjonalne elektrycznych/elektronicznych/programowalnych systemów związanych z bezpieczeństwem;

- IEC 61511 - Bezpieczeństwo funkcjonalne. Przyrzadowe systemy bezpieczeństwa dla sektora przemystu procesowego.

Zgodność z normami jest zapewniona poprzez wykorzystanie w procesie projektowania Systemu Zarządzania Bezpieczeństwem Funkcjonalnym. Relacje pomiędzy normami przedstawiono na rysunku 3.

4. Specyfikacja wymagań bezpieczeństwa dla przy-

rządowego systemu bezpieczeństwa (SIS - Safety Instrumented System)

Specyfikacja wymagań bezpieczeństwa powinna dotyczyć wymagań niezbędnych do zaprojektowania przyrządowego systemu bezpieczeństwa i powinna zawierać m.in.:

- identyfikację wszystkich przyrządowych funkcji bezpieczeństwa $\mathrm{z}$ określeniem wymaganego poziomu nienaruszalności bezpieczeństwa i rodzaju pracy,

- opis przyrządowych funkcji bezpieczeństwa (działania wymagane do osiągnięcia stanu bezpiecznego procesu, określenie wartości procesowych powodujących przywołanie, zdefiniowanie możliwych symulacji),

- wyszczególnienie i opis wszystkich interfejsów pomiędzy przyrządowym systemem bezpieczeństwa a pozostałymi systemami,
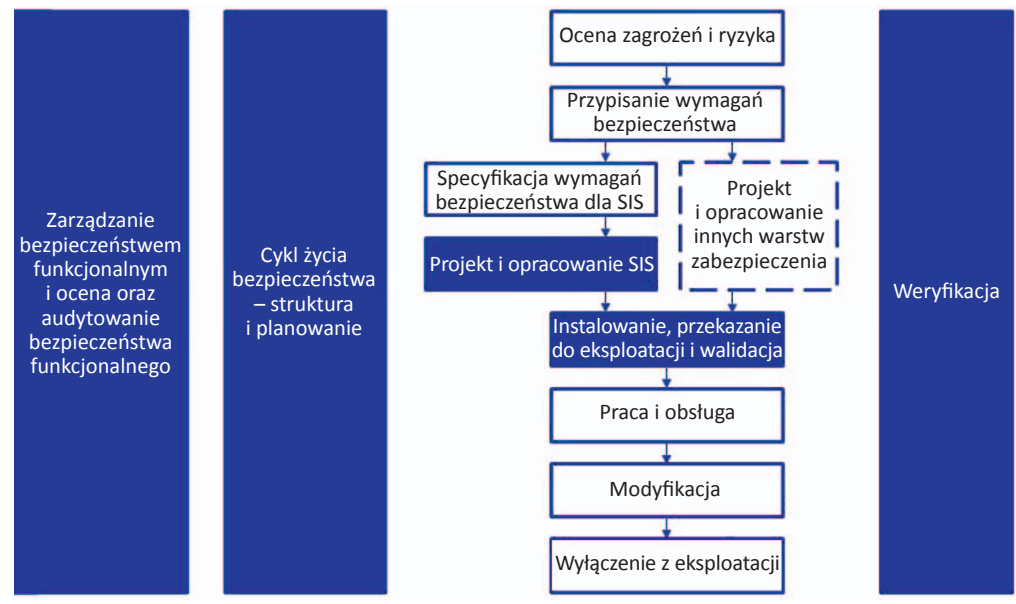

Rys. 4. Algorytm zarządzania bezpieczeństwem

Realizacja projektu opierała się łącznie na 13 procedurach i normach. Zgodność z normami potwierdzona jest certyfikatem wydanym przez niezależną jednostkę certyfikującą TÜV SÜD. 
6. Ocena bezpieczeństwa funkcjonalnego

Ocena bezpieczeństwa funkcjonalnego ma na celu stwierdzenie, czy zostało osiągnięte wymagane bezpieczeństwo funkcjonalne. Wykonywana jest przez niezależną organizację wchodzącą w skład grupy ABB. Podczas trwania projektu przeprowadza się jedną ocenę bezpieczeństwa funkcjonalnego, w następujących fazach:
- Preliminary - po przygotowaniu dokumentu SIS Functional Design Specification.

- Design - po zakończeniu fazy projektowania i przed przystąpieniem do prefabrykacji sprzętu oraz implementacji oprogramowania.

- Final-przed przystąpieniem do testu FAT.

Zakończenie każdej fazy jest dokumentowane.

\section{Podsumowanie}

1. Sterowniki systemu ESD są certyfikowane na zgodność z najnowszą normą IEC 61508 Edition 2.

2. W celu uzyskania pożądanego stopnia integralności bezpieczeństwa (SIL) w konstrukcji sterowników wykorzystuje się zróżnicowanie technologiczne podzespołów, a nie architekturę sterownika. System cechuje bardzo elastyczna architektura. Osiągnięty poziom bezpieczeństwa jest aprobowany przez większość liczących się firm z branży ropy i gazu.

3. Wykonawca systemu, ABB Polska, posiada wiedzę i umiejętności oraz wsparcie w zakresie systemów bezpieczeństwa potwierdzone przez certyfikat TÜV SÜD w zakresie systemu zarządzania bezpieczeństwem funkcjonalnym.

Bezpieczeństwo pracy tłoczni stanowi jeden z krytycznych elementów zapewnienia niezawodnego, bezpiecznego i ekonomicznego transportu gazu ziemnego. Decyzje o modernizacji systemów muszą uwzględniać kilka aspektów, m.in. wymagania prawne, ocenę stanu systemów, ryzyka związane z cyklem życia systemów, w tym uwarunkowane dostępnością części i serwisu, a także postęp technologiczny, dostępność nowych rozwiązań i potencjał możliwych usprawnień w wymiarze podwyższenia bezpieczeństwa, zwiększenia niezawodności i dostępności instalacji czy też ograniczenia kosztów transportu gazu.

Podejmowane od lat przez EuRoPol GAZ działania związane z zarządzaniem bezpieczeństwem technicznym, w tym zapewnianie wysokiego standardu bezpieczeństwa technicznego, oraz wkład w stabilny rozwój gospodarki zostały nagrodzone w 2014 roku wyróżnieniem Lider Bezpieczeństwa Technicznego w kategorii Eksploatujący. W 2015 roku decyzją Kapituły Konkursu im. Stanisława Staszica „Laur Innowacyjności” spółka za projekt „Usługa przesyłu gazu w aspekcie zwiększenia bezpieczeństwa osób, środowiska oraz techniki" została nagrodzona Złotym Laurem Innowacyjności w kategorii „Budownictwo i obiekty użyteczności publicznej, bezpieczeństwo i pożarnictwo". Zdobycie tych wyróżnień jest rezultatem wieloletniej współpracy z jednostką certyfikującą Urzędu Dozoru Technicznego UDT-CERT oraz dostawcami systemów bezpieczeństwa.

Przy pisaniu artykułu zostały wykorzystane instrukcje eksploatacyjne tłoczni gazu oraz materiały informacyjne firmy ABB

Prosimy cytować jako: Nafta-Gaz 2016, nr 7, s. 558-563, DOI: 10.18668/NG.2016.07.11

Artykuł nadesłano do Redakcji 1.02.2016 r. Zatwierdzono do druku 27.04.2016 r.

Artykuł powstał na podstawie referatu zaprezentowanego na Konferencji Naukowo-Technicznej FORGAZ 2016 „Techniki i technologie dla gazownictwa - pomiary, badania, eksploatacja”, zorganizowanej przez INiG - PIB w dniach 13-15 stycznia 2016 r. w Muszynie.

Piotr DWORAK

Zastępca Dyrektora Eksploatacji SGT

EuRoPol GAZ S.A.

ul. Topiel 12

00-342 Warszawa

E-mail:Piotr.Dworak@europolgaz.com.pl
Mgr inż. Andrzej CIŚLAK

Dyrektor Biura Eksploatacji Tłoczni SGT

EuRoPol GAZ S.A.

ul. Topiel 12

00-342 Warszawa

E-mail: Andrzej.Cislak@europolgaz.com.pl 